\title{
MENGUKUR TINGKAT KEPATUHAN KEPABEANAN PERUSAHAAN EKSPORT DAN IMPORT DI INDONESIA
}

\author{
Syaifullah ${ }^{1}$, Ramdany ${ }^{2}$ \\ ${ }^{1}$ Universitas Terbuka, syaifullah0285@gmail.com \\ ${ }^{2}$ STIE Muhammadiyah Jakarta, ramdany2021@gmail.com
}

\begin{abstract}
ABSTRAK
Penelitian ini bertujuan untuk membuktikan kepatuhan perusahaan eksport - import terhadap peraturan kepabeanan. Sample diambil dari perusahaan yang melakukan kegiatan eksport - import terdaftar di Bursa Efek Indonesia Tahun 2012 - 2017. Jumlah sampel sebanyak 157 perusahaan. Variabe bebas terdiri dari ukuran perusahaan, profitabilitas, likuiditas dan leverage. Sedangkan variabel terikat adalah kepatuhan kepabeanan (audit complienace). Hasil penelitian menunjukan tingkat kepatuhan perusahaan terhadap peraturan kepabeanan dalam tingkat sedang (moderat).

Kata Kunci : Ukuran perusahaan, Profitabilitas, Likuiditas, Leverage, Kepatuhan Kepabeanan (Audit Compliance)
\end{abstract}

\begin{abstract}
This study aims to prove the compliance of export - import companies on customs regulations. Samples were taken from companies conducting export - import activities listed on the Indonesia Stock Exchange in years 2012 - 2017. The number of samples was 157 companies. The independent variables are company size, profitability, liquidity and leverage. While the dependent variable is customs compliance (audit compliance). The results showed the level of compliance companies on customs regulations in moderate..
\end{abstract}

Keywords: Company size, Profitability, Liquidity, Leverage, Customs Compliance (Audit Compliance)

Naskah diterima: 07-04-2020, Naskah dipublikasikan: 30-04-2020

\section{PENDAHULUAN}

Penelitian ini bertujuan untuk mengetahui tingkat kepatuhan terhadap peraturan kepabaenan perusahaan eksport dan import yang terdaftar di Bursa Efek Indonesia (BEI) kurun waktu 2012 - 2017 ditinjau dari segi ukuran perusahaan, profitabiltas, leverage, likuiditas dan karakter eksekutif. Pemerintah melalui Direktorat Jenderal Bea dan Cukai (DJBC) berupaya meningkat penerimaan negara dari aktifitas eksport dan import dengan meningkatkan kepatuhan perusahaan eksport dan import terhadap aturan yang berlaku. Kepatuhan dapat ditegakkan bilamana adanya kekuatan (authorities) dari pihak berwenang (Kirchler, 2007). DJBC sebagai pihak yang memegang kekuatan dapat menggunakan wewenangnya untuk mengarahkan perusahaan eksport dan import agar mematuhi aturan yang berlaku.

Berdasarkan hasil audit kepabeanan dan cukai yang dilakukan oleh Direktorat Jenderal Bea dan Cukai (DJBC) tahun 2013-2017 menunjukkan adanya beberapa ketentuan kepabeanan dan cukai yang belum sepenuhnya ditaati oleh importir maupun eksportir. Hal ini dapat dilihat dari jumlah nilai finalti yang dikenakan oleh negara terhadap importir maupun eksportir seperti yang dijelaskan dalam tabel dibawah ini. 
Tabel 1

Tagihan Finalti Audit Kepabeanan dan Cukai

Tahun 2013- 2017

\begin{tabular}{|c|r|c|c|}
\hline \multirow{2}{*}{ Tahun } & \multirow{2}{*}{$\begin{array}{c}\text { Jumlah } \\
\text { Perusahaan }\end{array}$} & \multicolumn{2}{|c|}{ Tagihan Audit (Rp juta) } \\
\cline { 3 - 4 } & 2 & Total & $\begin{array}{c}\text { Rata-Rata Finalti } \\
\text { Per Perusahaan }\end{array}$ \\
\hline 1 & 692 & $3=$ Total & $4=3 / 2$ \\
\hline 2013 & 317 & 5.058 .170 & 1.131 \\
\hline 2014 & 492 & 2.137 .086 & 10.888 \\
\hline 2015 & 425 & 1.822 .444 & 2.637 \\
\hline 2016 & 320 & 1.121 .835 & 3.091 \\
\hline 2017 & 2.246 & 11.250 .869 & 2.944 \\
\hline Total & & & \\
\hline
\end{tabular}

Sumber : Saifullah, 2019 - Data DJBC (diolah)

Jumlah finalti tersebut berasal dari beberapa pelanggaran aktifitas yang tidak sesuai dengan ketentuan aturan berlaku seperti kekeliruan pemberitahuan nilai pabean (under invoicing), kekeliruan pemberitahuan tarif bea masuk atau bea keluar, kekeliruan pemberitahuan jenis dan jumlah barang impor, dan kekeliruan pemberitahuan barang kena cukai yang mengakibatkan kurang bayar atas penerimaan negara di bidang kepabeanan dan cukai dan yang lainnya. Selisih (gap) antara pajak yang dibayar dengan pajak seharusnya dibayar mencerminkan tingkat kepatuhan wajib pajak terhadap peraturan pemerintah yang dinamakan sebagai tax gap (James dan Alley, 2002). Semakin tinggi tax gap semakin rendah tingkat kepatuhan importir dan eksportir terhadap peraturan kepabeanan dan semakin tinggi potensi kebocoran penerimaan negara.

Salah satu prinsip good corparate governance yaitu prinsip pertanggungjawaban (responsibility) mewajibkan manajemen melaksanakan tugasnya dengan itikad baik, penuh tanggung jawab dan kehati-hatian untuk kepentingan perusahaan berdasarkan peraturan yang berlaku. Semakin baik tata kelola perusahaan semakin patuh terhadap aturan (Ettredge, 2011). Kepatuhan terhadap peraturan juga bertujuan untuk menjaga kelangsungan bisnis perusahaan (going concern) khususnya terhadap peraturan impor, ekspor, atau barang kena cukai.

Tujuan pemerintah sebagai fiskus untuk memaksimalkan penerimaan negara dari pajak maupun dari penerimaan kepabeanan dan cukai sering tidak sejalan dengan tujuan perusahaan dalam memaksimalkan keuntungan (maximaze profit). Hal ini karena pajak dan pungutan negara lainnya akan menjadi faktor mengurangi laba. Perbedaan kepentingan antara pemerintah selaku pemangku kepentingan (principal) dengan kepentingan perusahaan (agent) akan menyebabkan konflik (agency theory). Manajemen cenderung untuk mengurangi pembayaran pajak dan pungutan negara lainnya yang menyebabkan berkurangnya penerimaan negara (Diantari dan Ulupui, 2016).

Manajemen perusahaan berupaya meningkatkan kinerja perusahaan dengan optimal dari sisi profitabilitas, leverage, maupun likuiditas yang tercermin dalam laporan keuangan sehingga lebih menarik bagi pemegang saham, kreditur, investor dan pihak lainnya. Laporan keuangan menggambarkan kondisi dan kinerja keuangan perusahaan pada satu periode tertentu. Laporan keuangan merupakan salah satu sumber informasi bagi pemerintah untuk menilai kepatuhan kewajiban fiscal perusahaan dalam periode tersebut, misalnya kenaikan nilai asset, nilai penjualan, profitabilitas, likuiditas, maupun leverage sebagai parameter untuk mengukur estimasi jumlah pungutan negara pada periode berjalan.

Ukuran perusahaan menunjukkan kestabilan dan kemampuan perusahaan untuk melakukan aktivitas ekonominya termasuk pemenuhan kewajiban kepada pemerintah dari sisi fiskal. Semakin 
besar ukuran perusahaan semakin patuh terhadap kewajiban perpajakannya (Hanlon, 2005; Tedds, 2006; Kurniasih, 2013; Richardson, 2013; Maimako, 2015; Akinboade, 2015. Namun tidak menutup kemungkinan semakin besar perusahaan tidak menunjukkan hubungan yang positip dengan tingkat kepatuhan terhadap aturan perpajakan (Hanlon, 2005; Tedds, 2006). Hal ini juga dibuktikan dengan penelitian Rego (2003), Otusanya (2011), Kamleitner (2012), Rusydi (2013), Nyamwanza, T (2014), yang menunjukkan hubungan negatif antara ukuran perusahaan dengan kepatuhan perpajakan.

Perusahaan besar akan lebih mempertimbangkan risiko dalam hal mengelola beban perpajakannya agar kelangsungan bisnis (going concern) tetap terjaga. Semakin besar ukuran perusahaan semakin berisiko jika bersengketa dengan otoritas perpajakan (bea cukai). Otoritas bea cukai dapat menerapkan sanksi terhadap eksportir dan importir berupa pembekuan ijin eksportir dan importir yang akan berdampak langsung terhadap operasional, likuiditas, tingkat laba, investasi dan nilai asset perusahaan.

Selain ukuran perusahaan, profitabilitas perusahaan juga merupakan indikator untuk menilai kepatuhan fiskal perusahaan (De Schoenmaker, 2014). Profitabilitas merupakan kemampuan suatu perusahaan untuk menghasilkan laba. Profitabilitas perusahaan dihasilkan dari penggunaan sumber daya yang dimiliki perusahaan, seperti aset, hutang dan modal saham (Sudana, 2009). Salah satu ukuran kesehatan perusahaan adalah tingkat profitabilitas. Oleh karena itu manajemen berupaya menjaga tingkat profitabilitas dalam level tertentu. Semakin tinggi tingkat profitabilitas laba semakin tinggi tingkat kepatuhan terhadap aturan perpajakan (Moazzem, 2015). Namun demikian masih terdapat kecenderungan semakin tinggi tingkat profitabilitas perusahaan semakin rendah tingkat kepatuhan terhadap aturan perpajakan (Otusanya, 2011; Rinaldi, 2015).

Likuiditas merupakan kemampuan perusahaan dalam memenuhi kewajiban jangka pendeknya (Mardiyanto, 2009). Likuiditas perusahaan diukur dengan rasio likuiditas. Rasio likuiditas yang tinggi menunjukkan likuiditas perusahaan dalam kondisi yang sehat dan mampu memenuhi kewajiban jangka pendeknya (Laksono, 2011; Suyanto 2012). Perusahaan yang memiliki rasio likuiditas rendah lebih cederung memiliki tingkat kepatuhan pajak yang rendah (Evans, 2008; Siahaan, 2005; Atawodi, 2012; Pratiwi 2014; Prayatni, 2016). Di negara berkembang dimana tingkat korupsinya masih tinggi ada kecenderungan perusahaan memiliki tingkat liquiditas yang cukup tinggi menunjukkan tingkat kepatuhan terhadap perpajakan masih rendah (Nyamwanza, 2014). Hal ini juga didukung oleh hasil penelitian Suyanto (2010), Putri (2014), Yogiswari (2017) bahwa,likuiditas perusahaan memiliki pengaruh negatif terhadap kepatuhan perpajakan.

Leverage menunjukkan penggunaan hutang dan kemampuan perusahaan dalam membayar kewajibannya. Hutang dianggap sebagai leverage (pengungkit) dapat meningkatkan kemampuan perusahaan dalam menghasilkan keuntungan (Kurniasih dan Sari, 2013; Anwar, 2015). Pada umumnya pembelian barang modal asal import dengan nilai besar dibiayai dari hutang. Perusahaan mendapat keuntungan pajak dari penggunaan hutang berupa biaya bunga (Modigliani dan Miller, 1958). Biaya bunga yang dibebankan dalam laporan keuangan mengurangi laba dan selanjutnya mengurangi besar pajak penghasilan badan. Dari sisi perpajakan, semakin besar nilai hutang maka semakin besar nilai bunga sebagai pengurang jumlah pajak. Namun dari sisi kepabeanan justru sebaliknya bahwa semakin besar hutang impor maka semakin besar bea masuk dan pajak impor yang wajib disetor ke negara. Semakin tinggi tingkat leverage semakin tinggi tingkat kepatuhan terhadap aturan perpajakan (Kurniasih dan Sari, 2013).

Berdasarkan realitas dan gap yang terjadi dilapangan, penelitian ini mengangkat topik "Mengukur Tingkat Kepatuhan Kepabeanan Perusahaan Eksport dan Importir, Studi Kasus pada Perusahaan terdaftar di Bursa Efek Jakarta dari tahun 2012 - 2017”. Tingkat kepatuhan aturan dari importir ditinjau dari aspek ukuran perusahaan, profitabilitas, likuiditas, leverage dan karakter eksekutif sebagai variabel kontrol. 


\section{KAJIAN TEORI}

\section{Teori Kepatuhan (Compliance Theory)}

Kepatuhan adalah tindakan memenuhi keinginan atau permintaan pihak lain (Taylor, 2006). Subjek kepatuhan melibatkan dua atau lebih pihak yang saling berinteraksi yaitu pihak memerintahkan dan pihak yang diperintahkan untuk patuh. Sedangkan objek kepatuhan adalah keinginan atau permintaan orang atau pihak lain. Hasil dari interaksi tersebut akan menghasilkan kondisi patuh atau sebaliknya. Dalam tatanan organisasi teori kepatuhan adalah sebuah pendekatan terhadap internal atau struktur organisasi yang mengintegrasikan ide-ide dari model klasik dan partisipasi manajemen (Lunenburg, 2012). Selanjutnya Lunerburg (2012) menekankan adanya aspek internal organisasi dan reaksi kepatuhan tersebut dalam bentuk pastisipasi manajemen. Adanya tekanan atau permintaan pihak lain mengharuskan organisasi melakukan sesuatu sesuai kriteria sebagai bentuk partisipasi manajemen dalam memenuhi kepatuhan tersebut.

Kepatuhan dari sisi internal perusahaan dapat terbentuk dari enam faktor (Taylor, 2006) yaitu :
a. Informasi
b. Imbalan
c. Kepercayaan
d. Kekuasaan
e. Otoritas yang sah
f. Paksaan

\section{Teori Keagenan (Agency Theory)}

Teori keagenan didasari adanya pemisahan wewenang antara pihak pemilik perusahaan (principal) dan pihak manajemen sebagai pengelola perusahaan (agent) (Jensen dan Meckling, 1976). Hubungan keduabelah pihak (agency relationship) berdasarkan kontrak yang telah disepakati. Jensen dan Meckling (1976) menjelaskan pihak principal pendelegasian wewenang pengambilan keputusan bisnis kepada manajemen. Manajemen berhak mendapat kompensasi (agency cost) berupa kenikmatan (gaji dan fasilitas) dan bertanggungjawaban kepada pemilik perusahaan.

Pemisahan wewenang antara pemilik perusahaan dan manajemen menimbulkan asimestri informasi (Kholmi, 2017). Pemilik perusahaan mempunyai hak akses pada informasi internal perusahaan dan sebagai pengambil keputusan strategis jangka panjang dan global, namun tidak mengetahui operasi dan kinerja perusahaan secara riil dan menyeluruh. Di lain pihak, manajemen lebih mengetahui kondisi dan kinerja riil perusahaan dibanding pemilik perusahaan yang mengetahui kondisi perusahaan berdasarkan laporan keuangan yang dibuat manajemen. Oleh karena itu jika manajemen memberikan informasi yang kurang transparan akan merugikan pemilik perusahaan ketika mengambil keputusan strategis atau memungkinkan menguntungkan pihak manajemen. Permasalahan dalam teori keagenan ini muncul manakala setiap pihak bertindak memaksimakan kepentingannya masing-masing.

Dalam konsep agency theory, manajemen (agent) bekerja on behalf of the best interest of the shareholders (Kholmi, 2017). Namun, pada praktiknya beberapa manajemen bertindak untuk kepentingan dirinya sendiri. Manajemen mengetahui kondisi dan kinerja riil perusahaan dapat menggunakan akuntansi sebagai alat merekayasa laporankeuangan (engineering financial reporting). Jika hal ini terjadi akan merugikan berbagai pihak yang menggunakan informasi laporan keuangan untuk pengambilan keputusan dan pertanggungjawaban antara lain pemilik perusahaan dan pemerintah. Pemerintah sebagai pihak yang menggunakan laporan keuangan untuk mengawasi kepatuhan perusahaan akan ikut terkena dampak khususnya terkait realisasi penerimaan negara.

\section{Kepatuhan Peraturan Kepabeanan dan Cukai}

Tax compliance adalah kepatuhan wajib pajak dalam memenuhi kewajiban perpajakannya sesuai dengan aturan yang berlaku (James, 2002). Institusi Direktorat Jenderal Bea dan Cukai dan Direktorat Pajak berupaya meningkatkan penerimaan negara melalui peningkatan fungsi pelayanan dan 
pengawasan kepada pengguna jasa (wajib pajak) dalam bentuk simplifikasi aturan, kemudahan pelaksanaan aturan dan kepastian hokum.

Peningkatan fungsi pengawasan bertujuan untuk memastikan bahwa pemenuhan kewajiban perpajakan dalam kegiatan ekonominya sesuai dengan regulasi yang berlaku. Kepatuhan terhadap ketentuan perpajakan (tax compliance) dan kepatuhan terhadap peraturan kepabeanan dan cukai memiliki kesamaan dari sisi dampak terhadap optimalisasi penerimaan negara. Tingkat kepatuhan wajib pajak dapat diukur dari tax gap. Tax gap adalah perbedaan antara aturan perpajakan dengan realisasi yang dilaksanakan oleh wajib pajak. Tax gap ini dapat pula diartikan sebagai perbedaan antara besaran pajak yang seharusnya diterima negara dengan realisasi pembayaran oleh wajib pajak..

Kriteria kepatuhan peraturan Kepabeanan dan Cukai diatur dalam Peraturan Menteri Keuangan nomor 229/ PMK.04/2015, tentang Mitra Utama, sebagaimana telah diubah dengan Peraturan Menteri Keuangan nomor 211/PMK.04/ 2016, yang kemudian diturunkan dalam Peraturan Direktur Jenderal Bea dan Cukai nomor PER-11/BC/2017, tentang Petunjuk Pelaksanaan Mitra Utama Kepabeanan. Peraturan tersebut di atas mengatur kriteria-kriteria pengguna jasa yang dianggap patuh terhadap peraturan kepabeanan dan cukai selama melaksanakan kegiatan ekonominya :

a. Tidak pernah melakukan kesalahan mencantumkan jumlah, jenis barang, dan/atau nilai pabean yang bersifat material atau signifikan dalam pemberitahuan pabean.

b. Tidak pernah menyalahgunakan fasilitas di bidang kepabeanan dan/atau cukai yang bersifat material dan signifikan.

c. Tidak terdapat rekomendasi berdasarkan hasil audit yang menyatakan sistem pengendalian internal tidak baik dan/atau tidak dapat dilakukan audit (unauditable)

d. Tidak pernah meminjamkan modul kepabeanan dan cukai kepada pihak lain.

\section{Ukuran Perusahaan}

Ukuran perusahaan merupakan skala besar kecil perusahaan berdasarkan ukuran tertentu. Ukuran perusahaan adalah struktur properti perusahaan dalam bentuk volume penjualan, aset bersih, pelanggan, atau jumlah orang yang dipekerjakan dalam perusahaan (Theodore, 2009). Ukuran perusahaan menggambarkan kemampuan perusahaan dalam kepemilikan aset, modal, atau kemampuan dalam penjualan (omset). Ukuran perusahaan menggambarkan besar kecilnya suatu perusahaan yang dapat dinilai dari total aset yang dimiliki, jumlah penjualan, rata- rata total penjualan dan rata-rata aset (Wibawati, 2014).

Ukuran perusahaan dapat diproksi dengan logaritma natural (Ln) dari nilai total aset. Perusahaan besar cenderung akan melakukan diversifikasi usaha lebih banyak daripada perusahaan kecil. Oleh karena itu, risiko kegagalan dalam menjalankan usaha atau kebangkrutan akan lebih kecil. Organisasi besar cenderung memiliki lebih banyak spesialisasi, departemenisasi, sentralisasi, dan aturan dan peraturan daripada organisasi kecil (Theodore, 2009).

Perusahaan besar dipandang lebih mampu menghadapi krisis dan permasalahan dalam menjalankan usahanya karena perusahaan besar memiliki kontrol yang lebih baik terhadap kondisi pasar, memiliki akses yang lebih baik terhadap sumber- sumber informasi eksternal dibandingkan dengan perusahaan kecil (Sholichah, 2015). Selain itu, perusahaan besar menjadi perhatian pemerintah sehingga lebih patuh pada regulasi pemerintah. Wajib pajak besar memiliki tingkat kesadaran pajak lebih tinggi dibanding wajib pajak kecil (Suryadi, 2006).

\section{Profitabilitas}

Profitabilitas merupakan kemampuan suatu perusahaan untuk menghasilkan laba dengan menggunakan sumber daya yang dimiliki perusahaan, seperti asset, hutang dan modal (Sudana, 2009). Untuk mengukur tingkat profitabilitas perusahaan digunakan rasio profitabilitas atau juga dikenal dengan rasio rentabilitas.

Rasio profitabilitas merupakan rasio untuk menilai kemampuan perusahaan dalam mencari 
keuntungan (Lanawati, 2015). Rasio ini juga memberikan ukuran tingkat efektifitas manajemen perusahaan dalam menghasilkan laba dari pemanfaatan aset, hutang dan modal. Tujuan penggunaan rasio profitabilitas sebagai berikut :

1. Untuk mengukur laba yang diperoleh perusahaan dalam satu periode tertentu

2. Untuk menilai posisi laba perusahaan tahun sebelumnya dengan tahun ini

3. Untuk menilai perkembangan laba dari waktu ke waktu

4. Untuk menilai besarnya laba bersih sesudah pajak dengan modal sendiri

5. Untuk mengukur produktivitas seluruh dana perusahaan yang digunakan, baik modal pinjaman maupun modal sendiri.

\section{Likuiditas}

Likuiditas adalah kemampuan perusahaan dalam memenuhi kewajiban jangka pendeknya atapun hutang jangka panjang yang akan jatuh tempo (Mardiyanto 2009). Likuiditas perusahaan diukur dengan rasio likuiditas. Rasio Likuiditas digunakan untuk mengukur kemampuan perusahaan dalam memenuhi kewajiban jangka pendek, baik kewajiban kepada pihak luar (eksternal) maupun kewajiban dalam membiayai operasional perusahaan (internal).

Rasio likuiditas juga dikenal dengan rasio modal kerja yang digunakan untuk mengukur likuiditas perusahaan dengan membandingkan komponen di laporan posisi keuangan yaitu total asset lancar dengan total hutang lancar (Lanawati, 2015). Rasio likuiditas mengukur jumlah kas atau jumlah investasi yang dapat dikonversikan atau diubah menjadi kas untuk membayar pengeluaran, tagihan, dan seluruh kewajiban lainnya yang sudah jatuh tempo (Subramanyam, 2009). Jenis-Jenis rasio likuiditas yang sering digunakan seperti rasio lancar (current ratio), rasio sangat lancar ( quick ratio atau acid test ratio), rasio kas (cash ratio), rasio perputaran kas (cash turnover), working capital to total asset (WCTA).

\section{Leverage}

Solvabilitas adalah kemampuan perusahaan memenuhi seluruh kewajiban hutang jangka pendek maupun hutang jangka panjang (Reksoprajitno, 1993). Secara umum solvabilitas menunjukkan seberapa besar penggunaan hutang perusahaan dalam kegiatan operasionalnya (operasional leverage) maupun kegiatan pendanaannya (financing leverage) dan kemampuan perusahaan dalam membayar hutang-hutangnya tersebut. Hutang dianggap sebagai leverage (pengungkit) yang dapat meningkatkan kemampuan perusahaan dalam menghasilkan keuntungan (Anwar, 2015). Penggunaan hutang yang optimal dengan mempertimbangkan resiko dan return yang diterima akan meningkatkan keuntungan potensial perusahaan. Leverage menujukkan hubungan total aset dan penggunaan hutang untuk meningkatkan laba (Puspitasari, 2014).

Untuk mengetahui tingkat leverage perusahaan dapat dilakukan menggunakan rasio leverage. Rasio Leverage ini membandingkan keseluruhan beban hutang perusahaan terhadap aset atau ekuitasnya. Dari sisi aset, rasio ini menunjukkan porsi kepemilikan aset oleh kreditor (pemberi hutang). Selain itu, rasio ini juga menunjukkan tingkat resiko yang dihadapi perusahaan dari penggunaan dana eksternal berupa hutang. Rasio Leverage yang sering digunakan yaitu Debt to Total Asset Ratio merupakan perbandingan antara total hutang dengan total aset perusahaan. Semakin besar rasio ini menujukkan semakin besar resiko (leverage risk) yang dihadapi perusahaan (Anwar, 2015). Debt to Equity Ratio merupakan perbandingan antara total hutang (Liabilities) dengan total modal (Equity). Rasio ini mengukur persentase modal perusahaan yang disediakan oleh kreditor (Brigham dan Houston, 2014).

\section{PENGEMBANGAN HIPOTESIS}

\section{Pengaruh Ukuran Perusahaan terhadap Tingkat Kepatuhan}

Ukuran perusahaan merupakan salah satu faktor yang mempengaruhi tingkat kepatuhan terhadap perpajakan. Penelitian yang dilakukan oleh Mukhatob (2007), Hani (2010), Richardson (2013), menemukan adanya hubungan yang positip antara ukuran perusahaan dengan tingkat kepatuhan 
terhadap perpajakan. Artinya semakin besar ukuran perusahaan semakin tinggi tingkat kepatuhan terhadap perpajakan.

Berbeda dengan hasil penelitian yang dilakukan oleh Rusydi (2013) menemukan tidak ada hubungan antara ukuran perusahaan dengan tingkat kepatuhan terhadap perpajakan. Penelitian yang dilakukan oleh Rego (2003) menemukan hal yang sebaliknya bahwa semakin besar ukuran perusahaan semakin rendah tingat kepatuhan terhadap perpajakan.

Berdasarkan hasil penelitian diatas diambil kesimpulan hipotesis penelitian :

HA1 = Ada pengaruh ukuran perusahaan terhadap kepatuhan kepabeanan

\section{Pengaruh Profitabilitas Perusahaan terhadap Tingkat Kepatuhan}

Profitabilitas merupakan salah satu faktor yang dapat mempengaruhi tingkat kepatuhan perusahaan terhadap perpajakan. Semakin tinggi tingat profitabilitas semakin tinggi tingkat kepatuhan terhadap perpajakan. Penelitian yang dilakukan oleh Mukhatob (2007) menemukan adanya hubungan yang positip antara profitabilitas dengan tingkat kepatuhan perpajakan. Lain halnya dengan hasil penelitian Rosalia (2017) tingkat profitabilitas tidak berpengaruh terhadap penghindaran pajak.

Berdasarkan hasil penelitian diatas diambil kesimpulan hipotesis penelitian :

HA2 = Ada pengaruh ukuran profitabilitas terhadap kepatuhan kepabeanan

\section{Pengaruh Liquiditas Perusahaan terhadap Tingkat Kepatuhan}

Likuiditas merupakan kas yang digunakan oleh perusahaan untuk mendukung kegiatan operasional harian. Kewajiban perpajakan adalah kewajiban jangka pendek. Artinya semakin tinggi tingkat likuiditas perusahaan semakin tinggi tingkat kepatuhan perpajakannya. Penelitian yang dilakukan oleh Adisamartha (2015) menemukan adanya hubungan positif pada tingkat kepatuhan perpajakan perusahaan. Lain halnya dengan penelitian yang dilakukan oleh Putri (2014), Yogiswari (2017), Suyanto (2010) bahwa tingkat likuiditas perusahaan berpengaruh negatif terhadap kepatuhan pajak perusahaan, artinya semakin tinggi tingkat likuiditas perusahaan semakin rendah tingkat kepatuhan perusahaan terhadap kepatuhan perpajakan.

Berdasarkan hasil penelitian diatas diambil kesimpulan hipotesis penelitian :

HA3 = Ada pengaruh likuiditas perusahaan terhadap kepatuhan kepabeanan

\section{Pengaruh Leverage Perusahaan terhadap Tingkat Kepatuhan}

Tingkat hutang berpengaruh terhadap tingkat kepatuhan perpajakan. Semakin tinggi tingkat hutang semakin rendah tingkat kepatuhan terhadap perpajakan. Hal ini dibuktikan dengan penelitian yang dilakukan oleh Anindyka (2018), Permata (2018), Ngadiman (2017), dan Suyanto (2012) bahwa adanya hubungan positip antara tingkat hutang dengan kepatuhan perpajakan.

Berdasarkan hasil penelitian diatas diambil kesimpulan hipotesis penelitian :

HA4 = Ada pengaruh tingkat hutang perusahaan terhadap kepatuhan kepabeanan

\section{METODOLOGI PENELITIAN}

\section{Populasi dan Sampel Penelitian}

Data pada penelitian ini diambil dari laporan audit DJBC dan laporan keuangan pengguna jasa kepabeanan dan cukai yang telah terdaftar di BEI kurun waktu 2012 - 2017. Teknik pengambilan sampel yang digunakan dalam penelitian ini adalah purposive sampling, yaitu dengan melakukan pemilihan anggota sampel yang memenuhi kriteria tertentu (Sugiyono, 2014). Kriteria dari perusahaan yang dijadikan sampel pada penelitian ini adalah :

1. Seluruh perusahaan yang melakukan kegiatan kepabeanan dan telah dilakukan audit kepabeanan periode 2012 - 2017

2. Jenis audit kepabeanan dan cukai yang dilakukan adalah audit terencana dan audit sewaktu-waktu bukan audit investigasi

3. Laporan hasil audit kepabeanan dan cukai telah dievaluasi oleh Subdit Evaluasi Audit Kepabeanan dan Cukai 
4. Merupakan perusahaan terbuka yang terdaftar di Bursa Efek Indonesia dan masih aktif melakukan kegiatan kepabeanan dan cukai

5. Memiliki laporan keuangan yang telah diaudit sejak tahun 2012 sampai 2017; Penentuan sampel penelitian ini diperoleh berdasarkan kriteria tersebut di atas dan hasilnya dapat dilihat pada tabel dibawah ini.

Tabel 2 - Penentuan Sampel

\begin{tabular}{|l|c|}
\hline \multicolumn{1}{|c|}{ Kriteria } & Jumlah \\
\hline $\begin{array}{l}\text { Hasil audit Kepabeanan dan Cukai (bukan audit investigasi) periode } \\
2012 \text { s.d. } 2017\end{array}$ & 2.246 \\
\hline $\begin{array}{l}\text { Auditee merupakan perusahaan terbuka yang masih aktif melakukan } \\
\text { kegiatan Kepabeanan dan Cukai }\end{array}$ & 163 \\
\hline Memiliki laporan keuangan audited 2012 s.d. 2017 & 157 \\
\hline
\end{tabular}

Sumber : Data diolah

\section{Operasionalisasi Variabel}

Operasionalisasi variabel adalah penentuan konstrak atau sifat terkait variabel dan cara mengukur atau mengoperasikannya sehingga variabel dapat diukur dan diteliti (Sugiyono, 2014). Operasionalisasi variabel dalam penelitian ini adalah sebagai berikut:

Tabel 3- Operasionalisasi Variabel Penelitian

\begin{tabular}{|c|c|c|c|}
\hline Variabel & Indikator & $\begin{array}{l}\text { Skala } \\
\text { Pengukuran }\end{array}$ & Sumber Data \\
\hline $\begin{array}{l}\text { Kepatuhan } \\
\text { Peraturan } \\
\text { Kepabeanan dan } \\
\text { Cukai }\end{array}$ & $\begin{array}{l}\text { Tagihan Audit } \\
\text { Kepabeanan dan Cukai }\end{array}$ & Interval & $\begin{array}{l}\text { Laporan Hasil Audit } \\
\text { Kepabeanan dan Cukai, } \\
\text { Sistem } \\
\text { Informasi Audit }\end{array}$ \\
\hline \multirow{2}{*}{$\begin{array}{l}\text { Ukuran } \\
\text { Perusahaan } \\
\text { (Hanlon, 2005) }\end{array}$} & $\begin{array}{l}\text { Total Aset (Logaritma } \\
\text { Natural) }\end{array}$ & Rasio & Laporan Keuangan \\
\hline & $\begin{array}{l}\text { Total Penjualan (Logaritma } \\
\text { Natural) }\end{array}$ & Rasio & Laporan Keuangan \\
\hline \multirow{2}{*}{$\begin{array}{l}\text { Profitabilitas } \\
\text { (Anwar, 2015) }\end{array}$} & ROA (Return on Asset) & Rasio & Laporan Keuangan \\
\hline & ROE (Return on Equity) & Rasio & Laporan Keuangan \\
\hline \multirow{2}{*}{$\begin{array}{l}\text { Likuiditas } \\
\text { (Anwar, 2015) }\end{array}$} & Current Ratio & Rasio & Laporan Keuangan \\
\hline & $\begin{array}{l}\text { Working Capital to Total } \\
\text { Assets (WCTA) }\end{array}$ & Rasio & Laporan Keuangan \\
\hline Leverage & $\begin{array}{l}\text { Debt to Total Asset Ratio } \\
(D A R)\end{array}$ & Rasio & Laporan Keuangan \\
\hline
\end{tabular}




\begin{tabular}{|l|l|l|l|}
\cline { 2 - 4 } (Anwar, 2015) & $\begin{array}{l}\text { Debt to Total Equity } \\
\text { Ratio (DTE) }\end{array}$ & Rasio & Laporan Keuangan \\
\hline
\end{tabular}

Sumber : Data diolah

Operasionalisasi variabel Kepatuhan Peraturan Kepabeanan dan Cukai (Y) mengacu pada kriteria kepatuhan berdasarkan pasal 3 Peraturan Direktur Jenderal Bea dan Cukai nomor PER11/BC/2017 tentang Petunjuk Pelaksanaan Mitra Utama Kepabeanan bahwa reputasi kepatuhan meliputi : (1) Tidak pernah melakukan kesalahan mencantumkan jumlah, jenis barang, dan/atau nilai pabean yang bersifat material atau signifikan dalam pemberitahuan pabean; (2) Tidak pernah menyalahgunakan fasilitas di bidang kepabeanan dan/atau cukai yang bersifat material dan signifikan; (3) Tidak terdapat rekomendasi berdasarkan hasil audit yang menyatakan sistem pengendalian internal tidak baik dan/atau tidak dapat dilakukan audit (unauditable). Kriteria kepatuhan peraturan kepabeanan dan cukai tersebut diukur berdasarkan jumlah tagihan audit kepabeanan dan cukai atas pelanggaran di bidang kepabeanan dan cukai dalam skala ordinal berdasarkan penilaian evaluasi hasil audit.

Tabel 4- Pengukuran Kepatuhan Kepabeanan dan Cukai

\begin{tabular}{|l|c|}
\hline $\begin{array}{l}\text { Nilai Tagihan Audit Kepabeanan } \\
\text { dan Cukai (Rupiah) }\end{array}$ & Skala \\
\hline 0 - 100 Juta & 4 \\
\hline 100 Juta - 500 Juta & 3 \\
\hline 500 Juta - 1 Miliar & 2 \\
\hline$>1$ Miliar & 1 \\
\hline
\end{tabular}

Sumber : Data diolah

\section{Model Penelitian}

Penelitian ini mengggunakan dua macam variabel, yaitu variabel terikat (dependent) dan variabel bebas (independent) Variabel terikat yaitu kepatuhan perusahaan terhadap peraturan kepabeanan dan cukai dengan indikator finalti tagihan audit kepabeanan dan cukai, sedangkan variabel bebas berupa ukuran perusahaan profitabilitas, likuiditas dan leverage.

\section{Gambar - Model Penelitian}

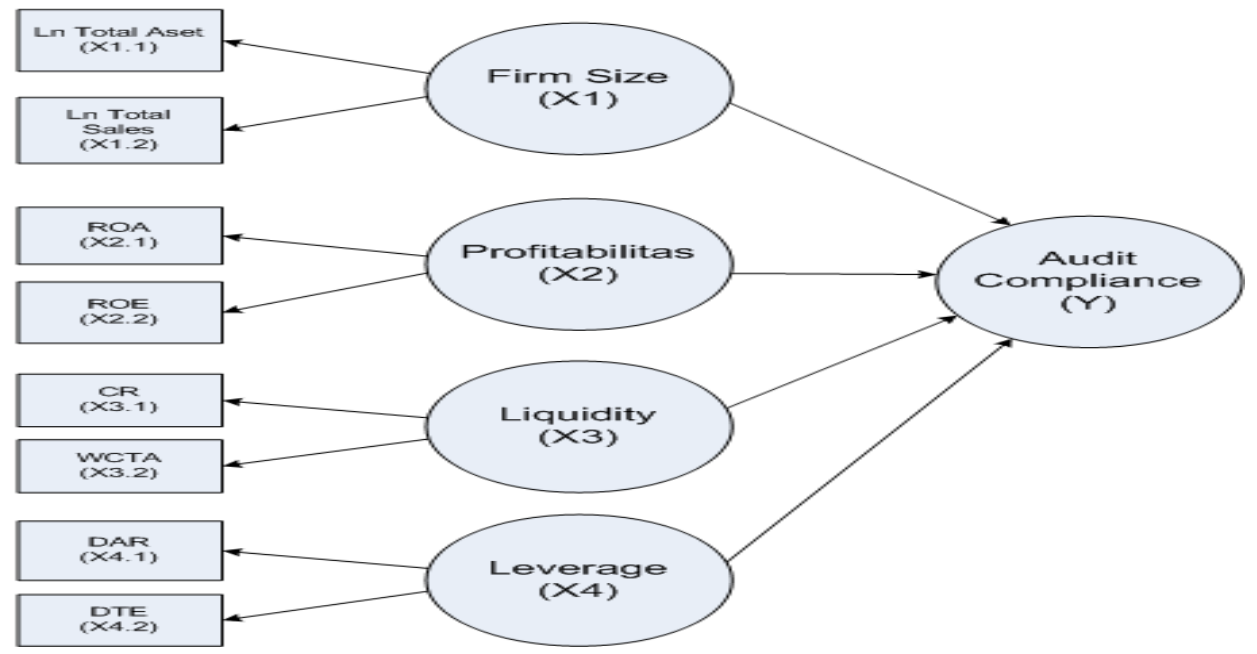


Sumber: Data diolah

Model persamaan dalam penelitian ini adalah :

$$
\mathrm{Y}=\gamma 1 \mathrm{X} 1+\gamma 2 \mathrm{X} 2+\gamma 3 \mathrm{X3}+\gamma 4 \mathrm{X} 4+\mathrm{e}
$$

\section{Keterangan :}

$\mathrm{Y} \quad=$ Variabel laten endogen $(\mathrm{Y})$ Kepatuhan Peraturan Kepabeanan dan Cukai.

$\mathrm{X} 1=$ Variabel laten eksogen Ukuran Perusahaan.

$\mathrm{X} 2=$ Variabel laten eksogen Profitabilitas.

$\mathrm{X} 3=$ Variabel laten eksogen Likuiditas.

$\mathrm{X} 4=$ Variabel laten eksogen Leverage.

$\gamma 1=$ Koefisien jalur yang menghubungkan variabel laten endogen (Y) Kepatuhan Peraturan Kepabeanan dan Cukai dengan variabel eksogen (X1) Ukuran Perusahaan.

$\gamma 2=$ Koefisien jalur yang menghubungkan variabel laten endogen $(\mathrm{Y})$ Kepatuhan Peraturan Kepabeanan dan Cukai dengan variabel eksogen (X2) Profitabilitas.

$\gamma 3=$ Koefisien jalur yang menghubungkan variabel laten endogen $(\mathrm{Y})$ Kepatuhan Peraturan Kepabeanan dan Cukai dengan variabel eksogen (X3) Likuiditas.

$\gamma 4=$ Koefisien jalur yang menghubungkan variabel laten endogen $(\mathrm{Y})$ Kepatuhan Peraturan

$\mathrm{E} \quad=$ error Kepabeanan dan Cukai dengan variabel eksogen (X4) Leverage.

\section{Model Pengukuran}

\section{Analisa Model Pengukuran (Outer Model)}

Analisa hubungan antara indicator dan variabel laten menggunakan pendekatan outer model. Outer model juga dinamakan outer relation atau measurement model (Jaya, 2008). Analisa outer model menggunakan indicator:

a. Discriminant Validity. Nilai cross loading faktor berguna untuk mengetahui apakah konstruk memiliki diskriminan yang memadai yaitu dengan cara membandingkan nilai loading pada konstruk yang dituju harus lebih besar dibandingkan dengan nilai loading dengan konstruk yang lain (Hussein, 2015).

b. Composite Reliability. Data yang memiliki composite reliability $>0,700$ mempunyai reliabilitas

$$
\rho c=\frac{\left(\Sigma \lambda_{i}\right)^{2}}{\left(\Sigma \lambda_{i}\right)^{2}+\Sigma_{i} \operatorname{var}\left(\varepsilon_{i}\right)}
$$

yang tinggi (Hussein, 2015). Composite reliability diukur dengan rumus sebagai berikut :

Keterangan :

$\mathrm{P} c=$ Composite reliability

$\Lambda=$ Lamnda merupakan loading faktor variabel laten

$\mathrm{E}=$ Epsilon merupakan kesalahan pengukuran atau noise

c. Multicolliniearity. Uji multicolliniearity dilakukan untuk mengetahui hubungan antar indikator. Untuk mengetahui apakah indikator formatif mengalami multicolliniearity dengan mengetahui 
nilai VIF. Nilai VIF antara 5 - 10 dapat dikatakan bahwa indikator tersebut terjadi multicolliniearity (Hussein, 2015).

\section{Analisa Model Struktural (Inner Model)}

Analisa Inner Model digunakan untuk menguji kesesuaian struktur model dengan desain penelitian. Pengujian inner model dilakukan dengan menggunakan uji determinasi (R-Square) untuk mengetahui dan menganalisa besar pengaruh total variabel bebas terhadap variabel terikat. Nilai RSquare sebesar 0,67 ke atas dalam kategori baik, 0,33 sampai dengan 0,67 kategori sedang, dan 0,19 sampai dengan 0,33 maka termasuk dalam kategori lemah (Chin ,1998). Sedangkan Hair et al. (2011) menyebutkan bahwa nilai R-Square sebesar 0,75 menggambarkan pengaruh yang substantial (kuat), jika nilai R-Square sebesar 0,50 dikategorikan moderate (sedang), dan nilai R-Square sebesar 0,25 dikategorikan week (lemah).

\section{Analisa Pengujian Hipotesis}

Pengujian hipotesis dilakukan dengan metode resampling Bootstrap (PLS). Penggunaan metode resampling memungkinkan berlakunya data terdistribusi bebas (distribution free) dan tidak memerlukan asumsi distribusi normal, serta tidak memerlukan sampel yang besar (Jaya, 2008). Statistik uji yang digunakan adalah statistik $\mathrm{t}$ atau uji $\mathrm{t}$ dengan melihat nilai $\mathrm{t}$-statistik dan nilai probabilitas ( $p$-value). Jika $p$-value $\leq 0,05$ (alpha $5 \%$ ), maka disimpulkan antar variabel memiliki pengaruh signifikan, dan jika Jika $p$-value $\geq 0,05$ maka disimpulkan antar variabel tidak memiliki pengaruh signifikan. Untuk menolak/menerima hipotesis menggunakan probabilitas maka Ha di terima jika nilai $\mathrm{p} \leq 0,05$ (Hussein, 2015).

\section{HASIL PENELITIAN}

\section{Hasil Penelitian}

\section{Skema Model Struktural (Inner Model) dan Model Pengukuran (Outer Model)}

Hasil penelitian model structural (inner model) dan model pengukuran (outer model) dapat dijelaskan dalam diagram jalur pada gambar dibawah ini.

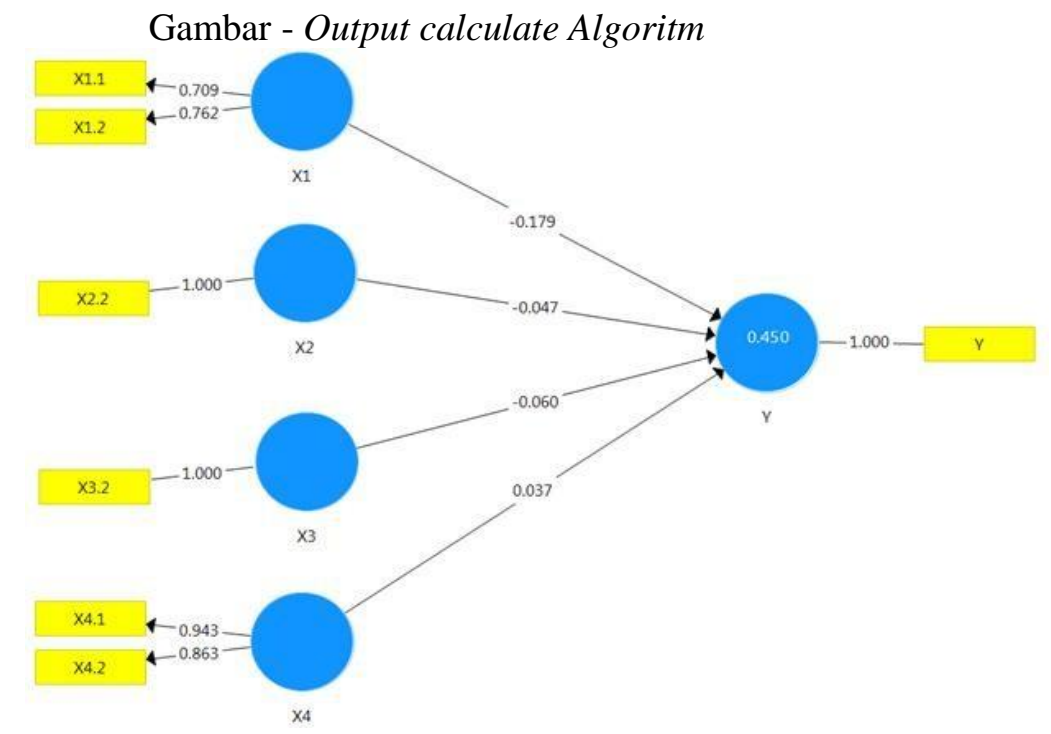


Tabel 5- Outer Loadings

\begin{tabular}{|l|c|c|c|c|c|}
\hline & X1 & X2 & X3 & X4 & Y1 \\
\hline X1.1 & $\mathbf{0 , 7 0 9}$ & - & - & - & - \\
\hline X1.2 & $\mathbf{0 , 7 6 2}$ & - & - & - & - \\
\hline X2.1 & - & $\mathbf{0 , 6 6 0}$ & - & - & - \\
\hline X2.2 & - & $\mathbf{0 , 9 9 6}$ & - & - & - \\
\hline X3.1 & - & - & $\mathbf{- 0 , 1 1 4}$ & - & - \\
\hline X3.2 & - & - & $\mathbf{0 , 9 4 8}$ & - & - \\
\hline X4.1 & - & - & - & $\mathbf{0 , 9 4 3}$ & - \\
\hline X4.2 & - & - & - & $\mathbf{0 , 8 6 3}$ & - \\
\hline Y & - & - & - & - & $\mathbf{1 , 0 0 0}$ \\
\hline
\end{tabular}

Indikator total aset (X1.1) dan total penjualan (X1.2) kuat menjelaskan variabel ukuran perusahaan dengan tingkat diatas $70 \%$. Indikator ROA (X2.1) moderat menjelaskan variabel profitabilitas, sedangkan indikator ROE (X2.2) sangat kuat menjelaskan variabel profitabilitas.Indikator current ratio (X3.1) sangat lemah menjelaskan variabel likuiditas dengan tingkat hubungan dibawah 70\%. Indikator workin capital on total asset (X3.2) sangat kuat menjelaskan variabel likuiditas mendekati 100\%. Indikator debt to total asset ratio (X4.1) dan debt to total equity ratio (X4.2) keduanya sangat kuat menjelaskan variabel leverage mendekati $100 \%$. Indikator tagihan audit kepabeanan dan cukai $(\mathrm{Y})$ merupakan satu-satunya indicator yang menjelaskan variabel kepatuhan peraturan kepabeanan dan cukai mendekati 100\%. Agar reliabilitas dari model penelitian tetap terjaga maka indicator dengan loading faktor $<0,7$ akan dihilangkan (Heir, 2014) sehingga ROA (X2.1) dan current ratio (X3.1) akan dihapus (drop).

Berdasarkan hasil loading gambar diatas, diperoleh model persamaan penelitian sebagai berikut

$$
\mathrm{Y}=-0,179 \mathrm{X} 1-0,047 \mathrm{X} 2-0,06 \mathrm{X} 3+0,037 \mathrm{X} 4+\mathrm{e}
$$

\section{Pengujian Outer Model (Goodness of fit model)}

\section{Pengujian Discriminant Validity}

Pengujian discriminant validity digunakan untuk melihat validitas dari konstruk yang terbentuk dibandingkan dengan konstruk yang lainnya. Hasil pengujian discriminant validity seperti dalam tabel berikut.

Tabel 6- Cross Loading

\begin{tabular}{|l|l|l|l|l|l|}
\hline & X1 & X2 & X3 & X4 & Y \\
\hline X1.1 & 0,709 & $-0,145$ & 0,170 & $-0,059$ & $-0,137$ \\
\hline X1.2 & 0,762 & 0,011 & 0,258 & $-0,013$ & $-0,149$ \\
\hline X2.2 & $-0,086$ & 1,000 & 0,034 & 0,197 & $-0,026$ \\
\hline X3.2 & 0,294 & 0,034 & 1,000 & $-0,088$ & $-0,117$ \\
\hline X4.1 & $-0,071$ & 0,168 & $-0,112$ & 0,943 & 0,044 \\
\hline
\end{tabular}




\begin{tabular}{|l|c|c|c|c|c|}
\hline $\mathbf{X 4 . 2}$ & 0,000 & 0,196 & $-0,031$ & 0,863 & 0,029 \\
\hline $\mathbf{Y}$ & $-0,195$ & $-0,026$ & $-0,117$ & 0,042 & 1,000 \\
\hline
\end{tabular}

Sumber : Data Sekunder diolah

Masing-masing indikator hasil loading factor konstruk lebih tinggi dibandingkan dengan loading factor kepada konstruk lain. Berdasarkan pengujian discriminant validity diatas dapat disimpulkan bahwa model tersebut fit.

\section{Pengujian Composite Realibility}

Pengujian realibilitas bertujuan untuk membuktikan akurasi dan konsistensi konstruk. Hasil composite reliability ditunjukan pada tabel berikut.

Tabel 7- Composite Reliability

\begin{tabular}{|l|c|c|}
\hline & $\begin{array}{l}\text { Composite } \\
\text { Reliability }\end{array}$ & $\begin{array}{l}\text { Average Variance } \\
\text { Extracted (AVE) }\end{array}$ \\
\hline X1 & $\mathbf{0 , 7 0 2}$ & $\mathbf{0 , 5 4 1}$ \\
\hline X2 & $\mathbf{1 , 0 0 0}$ & $\mathbf{1 , 0 0 0}$ \\
\hline X3 & $\mathbf{1 , 0 0 0}$ & $\mathbf{1 , 0 0 0}$ \\
\hline X4 & $\mathbf{0 , 9 0 0}$ & $\mathbf{0 , 8 1 8}$ \\
\hline Y & $\mathbf{1 , 0 0 0}$ & $\mathbf{1 , 0 0 0}$ \\
\hline
\end{tabular}

Sumber : Data diolah

Data yang memiliki composite reliability $>0,700$ mempunyai reliabilitas yang tinggi dengan nilai AVE yang diharapkan > 0,500.Pada tabel di atas menunjukkan bahwa nilai composite realibility setiap variabel lebih besar dari 0,700 dan nilai AVE diatas 0,5 sehingga dapat disimpulkan bahwa model/konstruk yang dipakai adalah reliabel.

\section{Pengujian Multicolliniearity}

Pengujian Multicolliniearity seperti ditunjukan dalam tabel berikut.

Tabel 8- Outer VIF Values

\begin{tabular}{|l|c|}
\hline & VIF \\
\hline X1.1 & 1,007 \\
\hline X1.2 & 1,007 \\
\hline X2.2 & 1,000 \\
\hline X3.2 & 1,000 \\
\hline X4.1 & 1,721 \\
\hline X4.2 & 1,721 \\
\hline Y & 1,000 \\
\hline
\end{tabular}

Sumber: Data Diolah

Berdasarkan tabel di atas terlihat bahwa nilai Collinearity Statistics (VIF) setiap indikator $<5$ sehingga 
dapat disimpulkan tidak terjadi multicolliniearity.

\section{Pengujian Inner Model}

Pengujian inner model dilakukan dengan melihat nilai R Square seperti dalam tabel berikut.

Tabel 9- R Square

\begin{tabular}{|l|r|c|}
\hline & R Square & R Square Adjusted \\
\hline $\mathrm{Y}$ & 0,450 & 0,406 \\
\hline
\end{tabular}

Sumber : Data diolah

Pada Tabel diatas menunjukkan bahwa nilai R Square sebesar 0,450 berarti variabel X1 (Ukuran Perusahaan), X2 (Profitabilitas), X3 (Likuiditas) dan X4 (Leverage) dapat menjelaskan variabel Y (Kepatuhan Peraturan Kepabeanan dan Cukai) sebesar 45\%. Sedangkan sisanya sebesar 55\% dijelaskan oleh faktor lainnya diluar variabel yang diteliti. Nilai R Square sebesar 0,450 dikategorikan sedang (Chin, 1998).

\section{Pengujian Hipotesis}

Analisis jalur (path analysis) pada model structural untuk mengetahui pola hubungan antara variabel endogen dengan variabel eksogen dengan melihat estimasi koefisien jalur yang diperoleh dengan prosedur boostrapping yang menghasilan Path Coefficients terlihat pada tabel berikut.

Tabel 10- Path Coefficients

\begin{tabular}{|l|c|c|c|c|c|}
\hline & $\begin{array}{c}\text { Original } \\
\text { Sample (O) }\end{array}$ & $\begin{array}{c}\text { Sample } \\
\text { Mean (M) }\end{array}$ & $\begin{array}{c}\text { Standard } \\
\text { Deviation } \\
\text { (STDEV) }\end{array}$ & $\begin{array}{c}\text { T Statistics } \\
(\mid \mathbf{O} / \text { STDEV|) }\end{array}$ & P Values \\
\hline $\mathbf{X 1}$-> Y & $-0,179$ & $-0,201$ & 0,084 & 2,136 & 0,033 \\
\hline $\mathbf{X 2}$-> Y & $-0,047$ & $-0,039$ & 0,106 & 0,443 & 0,658 \\
\hline $\mathbf{X 3}$-> Y & $-0,060$ & $-0,031$ & 0,106 & 0,565 & 0,572 \\
\hline $\mathbf{X 4}$-> Y & 0,037 & 0,062 & 0,117 & 0,318 & 0,750 \\
\hline
\end{tabular}

Sumber : Data diolah

Pengujian hipotesis dilakukan dengan melihat nilai t-statistik dan nilai probabilitas yang dihasilkan (uji t). Nilai t-statistik untuk alpha 5\% adalah 1,96. Sehingga kriteria penerimaan hipotesis adalah jika t-statistik $\geq 1,96$ dan ditolak jika t-statistik $<1,96$. Sedangkan pengujian hipotesis dengan menggunakan probabilitas diterima jika nilai $p$-value $\leq 0,05$ dan ditolak jika $p$-value $>0,05$ (Hussein, 2015). Berdasarkan $t$-statistics dan $p$-value yang dihasilkan dari proses bootstapping pengaruh antar variabel eksogen (X1, X2, X3 dan X4) terhadap variabel endogen (Y) dapat dilihat pada tabel berikut. 
Tabel 11- Pengaruh Variabel Eksogen Terhadap Variabel Endogen

\begin{tabular}{|l|l|l|l|}
\hline \multicolumn{1}{|c|}{ Variabel } & $\begin{array}{c}\text { t- } \\
\text { Statistik }\end{array}$ & p-value & Keterangan \\
\hline $\begin{array}{l}\text { Ukuran perusahaan (X1) terhadap } \\
\text { kepatuhan peraturan kepabeanan dan } \\
\text { cukai (Y) }\end{array}$ & 2,136 & 0,033 & Signifikan \\
\hline $\begin{array}{l}\text { Profitabilitas (X2) terhadap } \\
\text { kepatuhan peraturan kepabeanan } \\
\text { dan cukai (Y) }\end{array}$ & 0,443 & 0,658 & Tidak Signifikan \\
\hline $\begin{array}{l}\text { Likuiditas (X3) terhadap kepatuhan } \\
\text { peraturan kepabeanan dan cukai } \\
\text { (Y) }\end{array}$ & 0,565 & 0,572 & Tidak Signifikan \\
\hline $\begin{array}{l}\text { Leverage (X4) terhadap kepatuhan } \\
\text { peraturan kepabeanan dan cukai } \\
\text { (Y) }\end{array}$ & 0,318 & 0,750 & Tidak Signifikan \\
\hline
\end{tabular}

Sumber : Data diolah

Pada tabel di atas tampak bahwa ukuran perusahaan mempunyai pengaruh signifikan terhadap kepatuhan peraturan kepabenaan dan cukai sedangkan profitabilitas, likuiditas dan leverage mempunyai pengaruh yang tidak signifikan terhadap kepatuhan peraturan kepabenaan dan cukai. Selain itu, arah pengaruh hubungan antar variabel berdasarkan tabel 4.13 tampak bahwa Ukuran Perusahaan (X1), Profitabilitas (X2) dan Likuiditas (X3) terhadap Kepatuhan Peraturan Bea dan Cukai (Y) memiliki path coeffisients (koefisien jalur) dan original sample bernilai negatif yang menujukkan arah pengaruhnegative atau berbanding terbalik sedangkan pengaruh X4 (Leverage) memiliki koefisien jalur dan original sample bernilai positif yang menunjukkan arah pengaruh positif atau searah terhadap variabel terikat (endogen) Kepatuhan Peraturan Bea dan Cukai (Y).

Berdasarkan hubungan variabel pada model struktural, maka pernyataan hasil pengujian setiap hipotesis dapat dilihat pada tabel berikut.

Tabel 12- Hasil Pengujian Hipotesis

\begin{tabular}{|l|l|l|l|}
\hline Hipotesis & \multicolumn{1}{|c|}{ Pernyataan } & $\begin{array}{l}\text { Original } \\
\text { Sample }\end{array}$ & Keterangan \\
\hline H01 & $\begin{array}{l}\text { Ukuran perusahaan (X1) tidak } \\
\text { mempunyai pengaruh terhadap kepatuhan } \\
\text { peraturan kepabeanan dan cukai (Y) }\end{array}$ & $-0,179$ & Diterima \\
\hline H02 & $\begin{array}{l}\text { Profitabilitas (X2) tidak mempunyai } \\
\text { pengaruh terhadap kepatuhan peraturan } \\
\text { kepabeanan dan cukai (Y) }\end{array}$ & $-0,047$ & Diterima \\
\hline
\end{tabular}




\begin{tabular}{|l|l|l|l|}
\hline H03 & $\begin{array}{l}\text { Likuiditas (X3) tidak mempunyai } \\
\text { pengaruh terhadap kepatuhan peraturan } \\
\text { kepabeanan dan cukai (Y) }\end{array}$ & $-0,060$ & Diterima \\
\hline H04 & $\begin{array}{l}\text { Leverage (X4) tidak mempunyai pengaruh } \\
\text { terhadap kepatuhan peraturan kepabeanan } \\
\text { dan cukai (Y) }\end{array}$ & 0,037 & Ditolak \\
\hline
\end{tabular}

Sumber : Data diolah

\section{PEMBAHASAN}

\section{Pengaruh Ukuran Perusahaan terhadap Kepatuhan Peraturan Kepabeanan dan Cukai}

Hipotesis pertama menyatakan bahwa ukuran perusahaan (X1) mempunyai pengaruh terhadap kepatuhan peraturan kepabeanan dan cukai (Y). Berdasarkan hasil pengolahan data sampel diperoleh nilai original sample adalah sebesar $-0,179$ yang menunjukkan bahwa arah hubungan ukuran perusahaan dengan kepatuhan peraturan bea dan cukai adalah negatif atau berbanding terbalik. Pernyataan hipotesis pertama (HA1) ada pengaruh ukuran perusahaan terhadap kepatuhan peraturan kepabeanan dan cukai ditolak. Artinya, semakin tinggi tingkat ukuran perusahaan semakin rendah tingkat kepatuhan peraturan kepabeanan dan cukai. Pengaruh negative ini adalah signifikan karena nilai t-statistik > t-tabel yaitu 2,136>1,96 sedangkan nilai $p$ value $0,033<0,05$.

Nilai koefisien original sampel sebesar $-0,179$ menunjukkan bahwa jika total aset atau total penjualan berubah sebesar 1 satuan, maka tingkat kepatuhan terhadap peraturan kepabeanan dan cukai akan menurun sebesar 0,179 satuan, variabel lain dianggap tetap. Hasil penelitian ini sejalan dengan kondisi tax ratio Indonesia saat ini yang masih rendah dengan kisaran 11,6\% (Kontan, 22 Maret 2019).

\section{Pengaruh Profitabilitas terhadap Kepatuhan Peraturan Kepabeanan dan Cukai}

Hipotesis kedua penelitian ini adalah profitabilitas (X2) berpengaruh terhadap kepatuhan peraturan kepabeanan dan cukai. Berdasarkan hasil pengolahan data bahwa nilai original sample sebesar -0,047 yang menunjukkan arah hubungan profitabilitas dengan kepatuhan peraturan kepabeanan dan cukai adalah negatif atau berbanding terbalik. Pernyataan hipotesis kedua (HA2) ada pengaruh tingkat profitabiltias perusahaan terhadap kepatuhan peraturan kepabeanan dan cukai ditolak Artinya, semakin tinggi tingkat profitabilitas perusahaan semakin rendah tingkat kepatuhan peraturan kepabeanan dan cukai. Pengaruh negative ini adalah tidak signifikan karena nilai t-statistik 0,443 lebih kecil dibandingkan nilai t-tabel $1,96(0,443<1,96)$ dan nilai $p$-value $0,364>0,05$, artinya memungkinkan hubungan tingkat profitabilitas perusahaan dengan tingkat kepatuhan aturan kepabeanan dan cukai akan positip.

Nilai koefisien original sampel sebesar -0,047 menunjukkan bahwa jika tingkat profitabilitas berubah sebesar 1 satuan, maka tingkat kepatuhan terhadap peraturan kepabeanan dan cukai akan menurun sebesar 0,047 satuan, variabel lain dianggap tetap. Hasil penelitian ini mendukung penelitian Rosalia dan Sapari (2017) bahwa profitabilitas yang diproksikan dengan Return on Asset (ROA) tidak berpengaruh terhadap penghindaran pajak.

\section{Pengaruh Likuiditas terhadap Kepatuhan Peraturan Kepabeanan dan Cukai}

Hipotesis ketiga pada penelitian ini adalah likuiditas berpengaruh terhadap kepatuhan peraturan kepabeanan dan cukai. Berdasarkan hasil pengolahan data bahwa nilai original sample bernilai negatif sebesar -0,06 yang menunjukkan arah hubunganprofitabilitas terhadap Kepatuhan Peraturan Bea dan Cukai negative atau berbanding terbalik. Pernyataan hipotesis ketiga bahwa ada pengaruh likuiditas terhadap kepatuhan peraturan kepabeanan dan cukai ditolak. Artinya, semakin tinggi tingkat likuiditas perusahaan semakin rendah tingkat kepatuhan peraturan kepabeanan dan cukai.

Pengaruh negative ini adalah tidak signifikan karena nilai t-statistik 0,565 lebih kecil 
dibandingkan nilai t-tabel $1,96(0,565<1,96)$ dan nilai $p$-value sebesar $0,572>0,05$, artinya memungkinkan hubungan tingkat likuiditas perusahaan dengan tingkat kepatuhan aturan kepabeanan dan cukai akan positip.

Nilai koefisien original sampel sebesar -0,06 menunjukkan bahwa jika tingkat likuiditas berubah sebesar 1 satuan, maka tingkat kepatuhan terhadap peraturan kepabeanan dan cukai akan menurun sebesar 0,06 satuan, variabel lain dianggap tetap. Hasil penelitian ini sejalan dengan hasil penelitian Suyanto dan Supramono (2010), Putri (2014), Nugraheni (2015), dan Yogiswari dan Ramantha (2017) yang menyatakan bahwa likuiditas perusahaan berpengaruh negatif terhadap kepatuhan perpajakan.

\section{Pengaruh Leverage terhadap Kepatuhan Peraturan Kepabeanan dan Cukai}

Hipotesis keempat pada penelitian ini adalah leverage berpengaruh terhadap kepatuhan peraturan kepabeanan dan cukai. Berdasarkan hasil pengolahan data bahwa nilai original sample bernilai negatif sebesar 0,037 yang menunjukkan arahhubungan profitabilitas terhadapKepatuhan Peraturan Bea dan Cukai positip atau searah. Pernyataan hipotesis keempat bahwa ada pengaruh leverage terhadap kepatuhan peraturan kepabeanan dan cukai diterima. Artinya, semakin tinggi tingkat leverage perusahaan semakin tinggi tingkat kepatuhan peraturan kepabeanan dan cukai.

Pengaruh positip ini adalah tidak signifikan karena nilai t-statistik 0,318 lebih kecil dibandingkan nilai t-tabel $1,96(0,318<1,96)$ dan nilai $p$-value sebesar $0,750>0,05$, artinya memungkinkan hubungan tingkat leverage perusahaan dengan tingkat kepatuhan aturan kepabeanan dan cukai akan negative.

Nilai koefisien original sampel sebesar 0,037 menunjukkan bahwa jika tingkat leverage berubah sebesar 1 satuan, maka tingkat kepatuhan terhadap peraturan kepabeanan dan cukai akan meningkat sebesar 0,037 satuan, variabel lain dianggap tetap. Hasil penelitian ini searah dengan penelitian Ngadiman dan Puspitasari (2017), Anindyka (2018), dan Permata, Nurlaela dan Wahyuningsih (2018) bahwa leverage berpengaruh positif terhadap kepatuhan perpajakan

\section{PENUTUP}

Penelitian ini bertujuan untuk mengkonfirmasi hasil pemeriksaan Direktorat Jenderal Bea Cukai (DJBC) terhadap beberapa perusahaan yang melakukan kegiatan eksport dan import dan terdaftar di Bursa Efek Indonesia pada tahun 2012 - 2017. Finalti yang dikenakan kepada perusahaan eksport dan import kurun waktu tersebut dikonfirmasi dari ukuran perusahaan, profitabilitas, likuiditas dan leverage perusahaan. Apakah variabel tersebut cukup signifikan mempengaruhi tingkat kepatuhan terhadap aturan kepabeanan yang berlaku.

Hasil penelitian membuktikan bahwa ukuran perusahaan, profitabilitas dan likuiditas perusahaan berpengaruh negative terhadap kepatuhan aturan kepabeanan dan bertolak belakang dengan hipotesis. Kemudian leverage berpengaruh positip terhadap kepatuhan aturan kepabeanan dan searah dengan hipotesis. Hasil penelitian ini berhasil mengkonfirmasi hasil pemeriksaan yang dilakukan DJBC terhadap perusahaan eksport dan import yang dikenakan finalti pada kurun waktu tersebut. Ukuran perusahaan relative besar, tingkat profitabilitasnya cukup baik dan likuiditas yang memadai belum dapat mencerminkan tingkat kepatuhan kepabeanan cukup baik.

Di negara yang tingkat korupsinya masih tinggi fenomena seperti tersebut cukup lumrah (Torgler, 2007; Alon 2013). Tingkat korupsi yang tinggi menyebabkan kesenjangan kepatuhan dalam membayar pajak (Annafari, 2019). Artinya perusahaan kurang taat dengan peraturan yang berlaku karena ada celah yang dapat dimanfaatkan antara lain dengan melakukan kecurangan (fraud) dalam laporan, kolusi dengan petugas, sogokan dan sebagainya yang berdampak negative pada penerimaan negara dan menguntungkan bagi perusahaan. Kemungkinan lain rendahnya tingkat kepatuhan terhadap kewajiban perpajakan/kepabeanan disebabkan oleh sistem dan pengelolaan administrasi perpajakan masih lemah (Baum \& Gupta, 2017).

Tingkat leverage berhubungan positip terhadap kepatuhan kepabeanan, artinya semakin tinggi tingkat leverage perusahaan semakin tingi tingkat kepatuhan terhadap aturan kepabeanan. Hal ini dapat diterjemahkan bahwa perusahaan dengan tingkat leverage yang tinggi akan sangat berisiko bila tidak 
taat terhadap aturan perpajakan/kepabeanan. Finalti yang dikenakan negara terhadap kelalaian yang dilakukan oleh perusahaan dalam melaporkan kewajiban perpajakannya akan meningkatkan beban perusahaan dan akhirnya akan merugikan operasional perusahaan secara keseluruhan.

Memperhatikan hasil penelitian ini perlu adanya peningkatan pengawasan terhadap ekportir dan importir terkait dengan kepatuhan terhadap aturan bea cukai. Kemudian diperlukan reformasi yang menyeluruh di tatanan administrasi perpajakan dengan mempermudah sistem perpajakan, pemanfaatan teknologi informasi, dan tatakelola organisasi. Diharapkan dengan adanya perubahan yang mendasar tersebut dapat meningkatkan kepatuhan terhadap aturan kepabeanan dan akhirnya akan meningkatkan pendapatan negara.

\section{REFERENSI}

Adisamartha, I. B. P. F., \& Noviari, N. (2015). Pengaruh likuiditas, leverage, intensitas persediaan dan intensitas aset tetap pada tingkat agresivitas wajib pajak badan. E-Jurnal Akuntansi, 973-1000.

Alon, A., \& Hageman, A. M. (2013). The impact of corruption on firm tax compliance in transition economies: whom do you trust?. Journal of Business Ethics, 116(3), 479-494.

Anindyka, D., Pratomo, D., \& Kurnia, K. (2018). Pengaruh Leverage (DAR), Capital Intensity Dan Inventory Intensity Terhadap Tax Avoidance (Studi Pada Perusahaan Makanan Dan Minuan Di Bursa Efek Indonesia (BEI) Tahun 2011-2015). eProceedings of Management, 5(1).

Annafari, M. Tsani. Kompas 6 Juli 2019. Korupsi dan Kepatuhan Pajak. Hal 6.

Anwar, M. (2015). Manajemen Keuangan Bisnis (Ed. 2). Tangerang Selatan : Universitas Terbuka.

Baum, A., \& Gupta, S. (2017). Corruption, taxes and compliance. eJTR, 15, 190.

BPS. 2018. Realisasi Pendapatan Negara. Diunduh pada tanggal 05 November 2018. https://www.bps.go.id/statictable/2009/02/24/1286/realisasi-penerimaan- negara-miliar-rupiah2007-2017.html.

Brigham, E. F., \& Houston, J. F. (2014). Fundamentals of financial management. Mason USA : Cengage Learning.

Chin, W. W. (1998). The partial least Squares approach to structural equation modeling. Modern methods for business research, 295(2), 295-336.

De Schoenmaker, S., Van Cauwenberge, P., \& Vander Bauwhede, H. (2014). Effects of local fiscal policy on firm profitability. The Service Industries Journal, 34(16), 1289-1306.

Diantari, P. R., \& Ulupui, I. A. (2016). Pengaruh komite audit, proporsi komisaris independen, dan proporsi kepemilikan institusional terhadap tax avoidance. E-Jurnal Akuntansi, 702-732.

Direktorat Jenderal Bea dan Cukai. 2017. Peraturan Direktur Jenderal Bea dan Cukai nomor PER11/BC/2017 tentang Petunjuk Pelaksanaan Mitra Utama Kepabeanan

Direktorat Jenderal Bea dan Cukai. 2017. Peraturan Direktur Jenderal Bea dan Cukai nomor PER35/BC/2017 tentang Tata Laksana Audit Kepabeanan dan Cukai.

Direktorat Jenderal Perimbangan Keuangan. 2018. Nota Keuangan dan Rancangan Anggaran Pendapatan dan Belanja Tahun Anggaran 2018. Jakarta : Direktorat Jenderal Perimbangan Keuangan.

Ettredge, M., Johnstone, K., Stone, M., \& Wang, Q. (2011). The effects of firm size, corporate governance quality, and bad news on disclosure compliance. Review of Accounting Studies, 16(4), 866-889.

Evans, C. (2008). Containing tax avoidance: anti-avoidance strategies. UNSW Law Research Paper, (2008-40).

Hair, J. F., Sarstedt, M., Ringle, C. M., \& Mena, J. A. (2012). An assessment of the use of partial least Squares structural equation modeling in marketing research. Journal of the academy of marketing science, 40(3),414-433.

Hair, J.F., Hult, G.TM., Ringle, C., \& Srastedt, M. (2014). A Primer On Partial Least Squares Structural Equation Modeling (PLS-SEM). Sage Publication, Inc.

Hani, S., \& Lubis, M. R. (2016). Pengaruh Karakteristik Perusahaan Terhadap Kepatuhan Wajib Pajak. Jurnal Riset Akuntansi dan Bisnis, 10(1). 
Hanlon, M. (2005). The persistence and pricing of earnings, accruals, and cash flows when firms have large book-tax differences. The accounting review, 80(1), 137-166.

Hanlon, M., Mills, L. F., \& Slemrod, J. B. (2005B). An empirical examination of corporate tax noncompliance. Ross School of Business Paper, (1025).

Hussein, A. S. (2015). Penelitian bisnis dan manajemen menggunakan Partial Least Squares (PLS) dengan smartPLS 3.0. Modul Ajar

James, S., \& Alley, C. (2002). Tax compliance, self assessment system and tax administration. Journal of Finance, and Management in Public Services, 2(2), 27-42.

Jaya, I., Mindra, G. N., \& Sumertajaya, I. Made.(2008). Pemodelan Persamaan Struktural dengan Partial Least Square. Semnas Matematika dan Pendidikan Matematika .

Kamleitner, B., Korunka, C., \& Kirchler, E. (2012). Tax compliance of small business owners. International Journal of Entrepreneurial Behavior \& Research.

Kementerian Keuangan RI. 2015. Peraturan Menteri Keuangan Nomor 229/PMK.04/2015 tentang Mitra Utama Kepabeanan

Kementerian Keuangan RI. 2016. Peraturan Menteri Keuangan Nomor 211/PMK.04/2016 tentang Perubahan Atas Peraturan Menteri Keuangan Nomor 229/PMK.04/2015 tentang Mitra Utama Kepabeanan

Kementerian Keuangan RI. 2018. APBN KITA (Kinerja dan Fakta) edisi Januari 2018. Kholmi, M. (2017). Akuntabilitas dalam Perspektif Teori Agensi. Journal of

Kholmi, M. (2017). Akuntabilitas dalam Perspektif Teori Agensi. Journal of Innovation in Business and Economics, 2(02).

Kirchler, E. (2007). The economic psychology of tax behaviour. Cambridge University Press.

Kontan. Tax ratio Indonesia rendah, ini yang harus dilakukan otoritas pajak Jumat, 22 Maret 2019 / 21:54 WIB ,. https://nasional.kontan.co.id/news/tax-ratio-indonesia-rendah-ini-yang-harusdilakukan-otoritas-pajak

Kurniasih, T., \& Sari, M. M. R. (2013). Pengaruh Return On Assets, Leverage, Corporate Governance, Ukuran Perusahaan dan Kompensasi Rugi Fiskal Pada Tax Avoidance. Buletin Studi Ekonomi.

Laksono, J. P., \& ARDIYANTO, M. D. (2011). Analisis Faktor-Faktor yang Mempengaruhi Kepatuhan Wajib Pajak Badan pada Perusahaan Industri Manufaktur di Semarang (Doctoral dissertation, Universitas Diponegoro).

Lanawati, L., \& Amilin, A. (2015). Cash Ratio, debt to equity ratio, return on asset, firm size, growth dan dividen payout ratio pada Perusahaan Manufaktur di Indonesia. JRAP (Jurnal Riset Akuntansi dan Perpajakan), 2(01), 55-64.

Lunenburg, F. C. (2012). Compliance theory and organizational effectiveness. International journal of scholarly academic intellectual diversity, 14(1), 1-4.)

Maimako, S. S. (2015). The role of financial control institutions in promoting financial accountability in the public sector. A study of plateau state under democratic regime.

Mardiyanto, H. (2009). Inti sari manajemen keuangan. Grasindo.

Moazzem, K. G., \& Bashak, K. K. (2015, August). Margin and Its Relation with Firm Level Complaince; Illustration of the Bangladesh Apparel Value Chain. In a seminar titled "Bangladesh's Apparels Sector: Does Margin Matter for Ensurign Complaince.

Modigliani, F., \& Miller, M. H. (1958). The cost of capital, corporation finance and the theory of investment. The American, $1,3$.

Mukhatob, A. (2007). Pengaruh Struktur Keuangan, Struktur Modal, Profitabilitas, dan Good Corporate Governance terhadap Kepatuhan Pemenuhan Kewajiban Perpajakan Perusahaan yang Terdaftar di Bursa Efek Jakarta. Media Riset Akuntansi, Auditing \& Informasi, 7(1), 15-38.

Ngadiman, N., \& Puspitasari, C. (2017). Pengaruh Leverage, Kepemilikan Institusional, Dan Ukuran Perusahaan Terhadap Penghindaran Pajak (Tax Avoidance) Pada Perusahaan Sektor Manufaktur Yang Terdaftar Di Bursa Efek Indonesia 2010-2012. Jurnal Akuntansi, 18(3), 408421. 
Nugraheni, A. D., \& Purwanto, A. (2015). Faktor-faktor yang mempengaruhi kepatuhan Wajib Pajak orang pribadi (studi empiris pada Wajib Pajak di kota magelang) (Doctoral dissertation, Fakultas Ekonomika dan Bisnis).

Nyamwanza, T., Mavhiki, S., Mapetere, D., \& Nyamwanza, L. (2014). An analysis of SMEs' attitudes and practices toward tax compliance in Zimbabwe. SAGE Open, 4(3).

Otoritas Jasa Keuangan. 2015. Peraturan Otoritas Jasa Keuangan nomor 21/POJK.04/2015 tentang Penerapan Pedoman Tata Kelola Perusahaan Terbuka

Permata, A. D., Nurlaela, S., \& Wahyuningsih, E. M. (2018). Pengaruh Size, Age, Profitability, Leverage dan Sales Growth Terhadap Tax Avoidance Pada Perusahaan Sektor Industri Dasar dan Kimia di BEI. Seminar Nasional dan The 5th Call For Syariah Paper (SANCALL).

Pratiwi, I. G. A. M. A., \& Setiawan, P. E. (2014). Pengaruh Kesadaran wajib Pajak, Kualitas Pelayanan, Kondisi Keuangan Perusahaan, Dan Persepsi Tentang Sanksi Perpajakan Pada Kepatuhan Wajib Pajak Reklame Di Dinas Pendapatan Kota Denpasar. E-jurnal akuntansi, 139-153.

Prayatni, P. T. D., \& Jati, I. K. (2016). Pengaruh Kondisi Keuangan Perusahaan, Pemeriksaan Pajak Dan Sikap Wajib Pajak Terhadap Kepatuhan Wajib Pajak Hotel. E-Jurnal Akuntansi, 663-689.

Puspitasari, E. (2014). Analisis LaporanKeuangan. repository.ut.ac.id

Putri, L. T. Y. (2014). Pengaruh Likuiditas, Manajemen Laba Dan Corporate Governance Terhadap Agresivitas Pajak Perusahaan. Skripsi. Universitas Negeri Padang.

Putri, V. R., \& Putra, B. I. (2017). Pengaruh Leverage, Profitability, Ukuran Perusahaan Dan Proporsi Kepemilikan Institusional Terhadap Tax Avoidance. Jurnal Manajemen Dayasaing, 19(1), 1-11

Rego, S. O. (2003). Tax-avoidance activities of US multinational corporations. Contemporary Accounting Research, 20(4), 805-833.

Reksoprajitno, S. (1993). Analisis Laporan Keuangan: Analisis Rasio. Jakarta : Gunadarma

Republik Indonesia. 1995. Undang-Undang No. 10 tahun 1995 tentang Kepabeanan. Lembar Negara RI tahun 1995, No. 75

Republik Indonesia. 1995. Undang-Undang Nomor 11 tahun 1995 tentang Cukai. Lembar Negara RI tahun 1995, No. 23

Republik Indonesia. 2006. Undang-Undang Nomor 17 tahun 2006 tentang Perubahan Undang-Undang Nomor 10 tahun 1995. Lembar Negara RI tahun 2006, No. 93

Republik Indonesia. 2007. Undang-Undang Nomor 39 tahun 2007 tentang Perubahan Undang-Undang Nomor 11 tahun 1995. Lembar Negara RI tahun 2007, No. 105

Richardson, G., Taylor, G., \& Lanis, R. (2013). The impact of board of director oversight characteristics on corporate tax aggressiveness: An empirical analysis. Journal of Accounting and Public Policy, 32(3), 68-88.

Rinaldi \& Cheisviyanny, C. (2015). Pengaruh Profitabilitas, Ukuran Perusahaan dan Kompensasi Rugi Fiskal terhadap Tax Avoidance. SNEMA Fakultas Ekonomi Universitas Negeri Padang.

Rosalia, Y., \& Sapari, S. (2017). Pengaruh Profitabilitas, Likuiditas dan Corporate Governance Terhadap Penghindaran Pajak. Jurnal Ilmu dan Riset Akuntansi, 6(3).

Rusydi, M. K. (2014). Pengaruh ukuran perusahaan terhadap aggressive tax avoidance di Indonesia. Jurnal Akuntansi Multiparadigma, 4(2), 323-329.

Sholichah, W. A., \& Andayani, A. (2016). Pengaruh Struktur Kepemilikan, Ukuran Perusahaan Dan Leverage Terhadap Nilai Perusahaan. Jurnal Ilmu dan Riset Akuntansi, 4(10).

Siahaan, F. O. (2005). Faktor-Faktor yang Mempengaruhi Perilaku Kepatuhan Tax Professional dalam Pelaporan Pajak Badan pada Perusahaan Industri Manufaktur di Surabaya. Doctoral dissertation, UNIVERSITAS AIRLANGGA).

Subramanyam, K. R., \& John, J. Wild (2009) Financial Statement Analysis. America, New York: McGraw-Hill.

Sudana, Made I.(2009). Manajemen Keuangan: Teori dan Praktik.

Sugiyono, P. D. (2014). Metode Penelitian Kuantitatif Kualitatif dan R\&D . Indonesia: ALFABETA. 
Supriyadi, E. (2017). Perbandingan Metode Partial Least Square (PLS) dan Principal Component Regression (PCR) Untuk Mengatasi Multikolinearitas Pada Model Regresi Linear Berganda. Unnes Journal of Mathematics, 6(2), 117-128.Suryadi. 2006. Model Hubungan Kausal

Suyanto, K. D., \& Supramono, S. (2012). Likuiditas, Leverage, Komisaris Independen, dan Manajemen Laba terhadap Agresivitas Pajak Perusahaan. Jurnal Keuangan dan Perbankan, 16(2).

Suyanto, K. D., \& Supramono, S. (2012). Likuiditas, Leverage, Komisaris Independen, dan Manajemen Laba terhadap Agresivitas Pajak Perusahaan. Jurnal Keuangan dan Perbankan, 16(2).

Taylor, Y., Eliasson, A., Andrada, T., Kristo, D., \& Howard, R. (2006). The role of telemedicine in CPAP compliance for patients with obstructive sleep apnea syndrome. Sleep and Breathing, 10(3), 132138)

Theodore, J. (2009). Organizational size: A key element in the development of private enterprises in the less developed countries. The case of Ecuador. International Business \& Economics Research Journal, 8(7), 45- 49.

Torgler, B. (2007). Tax compliance and tax morale: A theoretical and empirical analysis. Edward Elgar Publishing

Yogiswari, N. K. K., \& Ramantha, I. W. (2017). Pengaruh Likuiditas Dan Corporate Social Responsibility Pada Agresivitas Pajak Dengan Corporate Governace Sebagai Variabel Pemoderasi. E-Jurnal Akuntansi, 2017(1), 730-759 